PRACTICAL LOG IC 


\section{PRACTICAL LOGIC}

by

ZYGMUNT ZIEMBIŃSKI

Adam Mickiewicz University, Poznań

with the Appendix on

DEONTIC LOGIC

by

ZDZISŁAW ZIEMBA

University of Warsaw

(6月

Springer-Science+Business Media, B.V 
This translation has been made from

L OGIKA PRAKT Y CZNA

Published in 1973 by Państwowe Wydawnictwo Naukowe, Warszawa

THE APPENDIX ON DEONTIC LOGIC has been written for the English edition

Translated from the Polish by Leon Ter-Oganian

Distributors for Albania, Bulgaria, Chinese People's Republic, Czechoslovakia, Cuba, German Democratic Republic, Hungary, Korean People's Democratic Republic, Mongolia, Poland, Rumania, Democratic Republic of Vietnam, the U.S.S.R. and Yugoslavia

ARS POLONA

Krakowskie Przedmiescie 7, 00-068 Warszawa, Poland

ISBN 978-94-017-5589-4 ISBN 978-94-017-5604-4 (eBook)

DOI 10.1007/978-94-017-5604-4

Copyright (C) by Springer Science+Business Media Dordrecht 1976

Originally published by PWN-Polish Scientific Publisbers-Warszawa in 1976.

Softcover reprint of the hardcover 1st edition 1976

No part of the material protected by this copyright notice may be reproduced or utilized in any form or by any means, electronic or mechanical, including photocopying, recording or by any informational storage and retrieval system, without written permission from the copyright owner 


\section{NTRODUCTION TO THE ENGLISH E D I T I O N}

The present book is an elementary textbook on logic for university undergraduates. It is intended mainly for students of law. For nineteen years this book has served students of law as well as those of other branches of the humanities in Poland. Apart from the two mimeographed editions (of 1956 and 1958), its subsequent editions (in 1959, 1960, $1963,1965,1969,1971$ and 1973) have undergone various modifications. A number of highly valuable contributions towards these improvements were made by the staff of the Section of Juridical Applications of Logic of the Adam Mickiewicz University in Poznan where this textbook was written, namely: Leszek Nowak, Assistant Professor, LL.D., Maciej Zieliński, LL.D., and Sławomira Wronkowska, LL.D. We are also indebted for good advice to numerous logicians and jurists in Poznan.

In comparison with the seventh Polish edition of 1973 the English translation contains modifications of a number of examples that were specifically Polish. It is first of all a contribution of the translator, $\mathbf{M r}$ Leon Ter-Oganian, M. A. The eighth Polish edition of this textbook recently published in 1974 contains many corrections, particularly in the Chapter XVIII on logical foundation of the interpretation of law and of juridical reasonings. The most important amplification, however, is the addition of a supplementary section on Deontic Logic written by Zdzislaw Ziemba (Assistant Professor, Ph.D., of Warsaw University), since it is this part of formal logic that should be of particular interest to jurists. In contrast to the rest of the book this section contains new and original conceptions.

The textbook contains the fundamental elements of knowledge in the field of semiotics (Part One: 'Formulation of Thoughts by Means of Words'), and in the field of formal logic and general methodology of sciences (Part Two: 'Foundation of Statements'). Semiotics, formal logic and the general methodology of sciences are jointly called by the name of logic in the widest sense of this word. The selection of materials from these fields and of supplementary information concerning other adjacent branches of knowledge, has been made primarily with a view 
to making more evident and contributing to the mastery of those skills which turn out to be useful in practice for the thinking processes of lawyers. This does not, of course, mean that the whole subject matter has been restricted to a choice of examples that might in one way or another be connected with juridical problems. In any cases such examples might not always be the most appropriate in view of their complicated character.

The final part of the textbook (Part Three: 'The Intelectual Work of Lawyers') contains the presentation of some specifically juridical applications of logic and an analysis of the intellectual activities of lawyers. The first two parts of the textbook constitute, however, an independent entity and may be used as an elementary textbook on logic for students of various branches of the humanities.

The juridical examples are borrowed from the body of laws in force in the Polish People's Republic. Consequently, they are concerned with a legal system of the Continental type which presents to the jurist mental problems completely different from those raised by Common Law systems. We would, however, expect that this book in its English version would be read not only by English or American readers. Besides, it might be very risky for a Polish jurist to express his opinions about problems belonging to the English juridical doctrine.

The textbook is intended also as an aid for student taking correspondence courses. It can be used independently of university lectures, but an effort must be made to study it systematically and to solve the exercises connected with each particular chapter.

The aim of the present book is not so much to transmit any definite amount of fundamental information belonging to the domain of logic, as to transmit some elements of a basic logical knowledge which is becoming increasingly more and more indispensable for any modern lawyer. It has also become the initial condition of progress in the juridical sciences. For that very reason the idea of introducing a course in logic into the curriculum of legal studies at Universities in Poland has proved to be highly useful over the past 29 years.

The disciplines embraced by the syllabus of the course in logic (in the wide sense of the word), in spite of their heterogeneous character, are linked together by the fact that they are all concerned in one way or another with forms of efficient thinking. 
In order to think efficiently it is necessary, first of all, to be able to formulate one's own thoughts clearly and unequivocally; to be conscious of how statements are used for description of the world, for the expression of our thoughts, for suggesting to other people some definite kind of behaviour or action. So it is necessary to become familiar with the fundamental principles in the field of semiotics, that is to say, the general science concerning signs, particularly word-signs (or linguistic signs). Within the scope of semiotics the following main branches are distinguished: (1) semantics, the general science of relations between linguistic signs on the one hand and what these signs refer to, on the other; (2) syntactics, the general science describing the types of linguistic signs and the rules of correctly joining them into compound expressions, and finally (3) pragmatics, the science dealing with problems concerning the relations between the linguistic signs and either the person uttering (the speaker) or the person receiving the utterances (the listener). Semiotics is a branch of science very close to linguistics. But it does not deal with studies of the meaning of certain definite expressions used in some national languages, or the syntax of particular languages, or actual acts of expressing some experience in the given languages. On the contrary, it is concerned with such general problems as: what does the meaning of expressions consist in; what are the fundamental kinds of expressions with regard to their syntactical role; what does the process of communication consist in; what is the manner in which misunderstandings arise, and so on. Consequently, we can distinguish general semantics from philological semantics, which deals with concrete national languages; we can also distinguish logical syntax, general syntax and the syntax of particular, individual natural languages. Differentiation between the problems belonging to logic and those belonging to philology have repeatedly created difficulties in researches concerning linguistic signs. The results of these two kinds of investigations are also not adequately co-ordinated.

In order to think efficiently, we must know which proposition results from what proposition. Formal logic (or logic in the narrow sense of the word) is the science of the relations occurring between the truth or falseness of some propositions with regard to their structure (form, formation), and particularly the relation of one proposition being implied by others. For instance, it asserts that from any proposition of 
he structure 'No $S$ is $P$ ' (thus, 'No Swede is Polish', 'No judge is a prosecutor', 'No student is illiterate', and so on) is implied a corresponding proposition of the structure 'No $P$ is $S$ ' (hence, for instance, 'No Pole is a Swede', 'No prosecutor is a judge', 'No illiterate person is a student', and so on). This means: if the former of such propositions is true, then the corresponding latter must also be true. On the other hand, formal logic points out that from a proposition of the structure 'Some $S$ is not $P$ ' does not follow, by virtue of its structure alone, a proposition of the type 'Some $P$ is not $S$ '. It may happen that the proposition of the former type is true (for instance, 'Some officers are not prosecutors'), but the corresponding proposition of the latter type is false (for instance, 'Some rosecutors a re not officers'). Formal logic, particularly in its contemporary state, is a science similar in many respects to mathematics, except that it is a more general branch of science than mathematics.

The general methodology of science is concerned with the methods (rules) of procedure applied for cognition of the world. Primarily its concern is the methods of foundation or demonstration of the truth of the statements formulated by us. It also deals with various intellectual activities which aim at ordering our knowledge into a coherent set of propositions constituting the corpus of a given scientific discipline, that is to say, a distinctly separate branch of learning. Methodology is a science similar in some respects to the technical sciences. Methodology describes the performance of certain actions, as do the technical sciences; in our case the description concerns the performance of some intellectual activities, such as inference, demonstration, explanation, or formulation of hypotheses. At the same time it teaches or instructs how these actions are to be performed in order to attain the required aimthe founded cognizance of truth. 
Part I

FORMULATION OF THOUGHTS BY MEANS

OF WORDS

CHAPTER I. SPEECH

$\S 1$. Speech and Thought

$\S 2$. A General Definition of Sign 3

$\S 3$. Verbal Signs and Their Shape $\quad 8$

$\S 4$. Communication by Means of Words 9

$\S 5$. Functions of Utterances 11

§6. Language 14

$\S 7$. Syntactical Categories. Syntactical Correctness of Expres$\begin{array}{ll}\text { sions } & 17\end{array}$

$\begin{array}{ll}\text { Exercises } & 22\end{array}$

CHAPTER II. NAMES

§ 1. The Concept of Names 24

$\S 2$. Concrete Names and Abstract Names 24

§3. The Designatum of a Name 26

§4. Individual Names and General Names 27

$\S 5$. Connotation of a Name 28

§ 6. Denotation of a Name 32

§. Determining and Abstracting 33

$\S 8$. Division of Names in Relation to the Number of Designata 34

§9. Collective Names 35

$\S 10$. Cleancutness of the Denotation of a Name 37

Exercises $\quad 39$

CHAPTER III. RELATIONS BETWEEN DENOTATIONS OF NAMES

$\S 1$. Usefulness of Determining the Relations between Denotations of Names 
$\S$ 2. Universal Class, Complementary Class 41

$\S 3$. Kinds of Relations between Denotations of Names 44

$\S 4$. Instances of Relations between Denotations of Names 47 Exercises $\quad 49$

CHAPTER IV. DEFINITIONS

$\S 1$. Real Definition and Nominal Definition 51

$\S 2$. The Tasks of Definitions 52

§. Structure of Definitions 56

$\S 4$. Conditions for Correctness of Definitions 61 Exercises $\quad 65$

CHAPTER V. PROPOSITIONS

$\S 1$. The Proposition (Statement) in the Logical Sense 67

$\S 2$. Logical Value of Propositions 69

$\S 3$. Objectiveness of Truth and Falseness of Propositions 70

§4. Elliptical Propositional Utterances 73

$\S 5$. Propositional Functions (Formulas) 75

§6. Structure of Propositions 77

$\S 7$. Proposition Equivalents in our Consciousness 83 $\begin{array}{ll}\text { Exercises } & 85\end{array}$

CHAPTER VI. TRUTH-FUNCTORS AND INTERPROPOSITIONAL CONNECTIVES OF NATURAL LANGUAGES

$\S 1$. The Concept of Truth-Functors 87

§ 2. Negation $\quad 94$

§3. Conjunction 99

$\S 4$. Non-exclusive Disjunction, Exclusive Disjunction and Alternative Denial 101

§5. Equivalence 104

§ 6. Implication and the Relation of Entailment 105 $\begin{array}{ll}\text { Exercises } & 111\end{array}$

CHAPTER VII. FUNDAMENTAL CONCEPTS CONCERNING RELATIONS

§ 1. Propositions Stating a Relation 114

$\S 2$. Symmetric, Asymmetric, and Non-Symmetric Relations 115 
§ 3. Transitive Relations

$\S 4$. Relation Ordering in a Class of Objects

CHAPTER VIII. EVALUATIVE UTTERANCES AND NORMS

$\S 1$. Evaluative Utterances versus Descriptive Utterances 122

$\S 2$. The Concept of Norms of Conduct 126

§3. Validity of Norms 130

$\S 4$. Verbal Form of Norms 136

$\S 5$. Structure of Norms of Conduct 138

Exercises 143

CHAPTER IX. MODAL EXPRESSIONS

$\S 1$. Interpretation of 'Must' and 'May' 146

$\S 2$. Modality of Propositions 151

§3. Deontic Modalities 153

Exercises $\quad 155$

CHAPTER X. QUESTIONS AND ANSWERS

$\S 1$. The Structure of a Question $\quad 157$

$\S 2$. Methods of Asking Questions 159

§3. Answers 162

Exercises 164

CHAPTER XI. CAUSES OF MISUNDERSTANDINGS

$\S 1$. Ambiguity of Words

$\S 2$. Specific Kinds of Ambiguity in Words and Linguistic Expressions

§ 3. Equivocations. Verbal Contentions 168

$\S 4$. Ambiguity in Compound Expressions 170

$\S 5$. Amphibolies 172

§6. Literal and Non-Literal Meaning 173

$\begin{array}{ll}\text { Exercises } & 174\end{array}$ 


\section{Part II \\ FOUNDATION OF STATEMENTS}

CHAPTER XII. DIRECT FOUNDATION

$\S 1$. Methods of Foundation

§ 2. Impressions and Apperceptions 180

§3. Observation 183

Exercises

CHAPTER XIII. DEDUCTIVE INFERENCE AND ITS LOGICAL BASES

A. GENERAL CONCEPTS

§ 1. Inference 186

§ 2. Inference Process and Relation of Entailment 187

§ 3. Logical Laws 188

§4. Deductive Inference 192

B. LOGICAL LAWS WITH PROPOSITIONAL VARIABLES

§ 5. Negation of Compound Propositions 194

§ 6. Transposition 197

§ 7. Laws of Syllogistic Structure 199

§ 8. Other Laws with Propositional Variables 203

C. LOGICAL LAWS WITH NAME VARIABLES

§ 9. Traditional Theory of Classes 209

$\S 10$. Relations of the Square of Opposition 211

$\S$ 11. Conversion, Obversion and Contraposition 214

$\S 12$. Laws of Categorical Syllogisms 217

D. FALLACIES IN DEDUCTIVE INFERENCE

$\S$ 13. Material Fallacy 223

$\S 14$. Formal Fallacy 224

Exercises $\quad 225$

CHAPTER XIV. PROBABILIFYING INFERENCES

§1. Reductive Inference 232

$\S 2$. Inductive Inference 235 
$\S 3$. Methods of Induction

4. Inference by Analogy

CHAPTER XV. THINKING WITH PRE-ASSIGNED TASKS

$\S 1$. Spontaneous Thinking and Thinking with Pre-Assigned Tasks

§ 2. Demonstration

§3. Testing

$\S 4$. Explanation

$\S 5$. Explanatory Hypotheses

$\S 6$. Theories

Exercises

CHAPTER XVI. PROBABILITY

§ 1. The meaning of the Word 'Probability'

$\S 2$. Probability as a Mathematical Concept

$\S 3$. Probability as a Frequency Concept

$\S 4$. Determination of Probability of a Complex of Events 267 Exercises

\section{Part III}

\section{THE INTELLECTUAL WORK OF LAWYERS}

CHAPTER XVII. LOGICAL FOUNDATIONS OF JUSTIFYING COURT JUDGEMENTS

$\S 1$. Structure of Judgement Justification

$\S 2$. Establishment of Facts

$\S 3$. Determination of Reliability of Witnesses 278

$\S 4$. Expert Opinions

$\S 5$. Legal Presumptions 282

§6. Circumstantial Evidence 284

$\S 7$. Types of Inference from Evidence in Court 287

$\S 8$. Establishment of the Actual State of Affairs and Subsumption

§ 9. Leeway of Subsumption $\quad 290$

Exercises 
CHAPTER XVIII. LOGICAL FOUNDATION OF THE INTERPRETATION OF LAW

$\S 1$. The Concept of Interpretation

$\S 2$. Types of Legal Provisions

§3. Linguistic Rules of Interpretation 305

§ 4. Teleological Rules of Interpretation 310

$\S 5$. Restrictive Interpretation and Extensive Interpretation $\quad 314$

§ 6. Juridical Inference 316

$\S 7$. Inferences Based on Logical Entailment of Norms 319

§ 8. Inferences Based on Instrumental Entailment of Norms 322

$\S 9$. Inferences Based on Assumption of Consistency of the 'Lawgiver's' Evaluations 324

Exercises

CHAPTER XIX. LOGICAL DIVISION AND ORGANIZATION OF WORK

$\S 1$. The Concept of Logical Division

$\S 2$. Conditions of Correct Logical Division 331

§ 3. Classification 335

$\S 4$. Differentiation of Types and Logical Division 337

Exercises

CHAPTER XX. METHODOLOGICAL CHARACTERISTICS

OF JURIDICAL SCIENCES

$\S 1$. General Methodology of Sciences and Specialistic Methodologies

$\S 2$. Variety of Problems and of Investigatory Methods in Juridical Sciences

$\S 1$. Arguing and Proving

$\S 2$. Disputation and its Kinds

$\S 3$. Organizing a Discussion

$\S 4$. Objections in Disputation 
APPENDIX

DEONTIC LOGIC

$\S 1$. Introduction 360

$\S 2$. A System of Deontic Logic

$\S 3$. Relative Deontic Systems

373

$\S 4$. Deontic Systems Based on Modal Logic

376

$\S 5$. A System of Deontic Logic with Quantifiers

381

$\S 6$. Consistency of Obligations

394

$\S 7$. Deontic Permission

401

$\S 8$. 'Paradoxical' Theorems of Deontic Logic

413

$\S 9$. Commitment

421

$\S 10$. Conclusion

425

INDEX 